\title{
CHARACTER EDUCATION OF ELEMENTARY SCHOOL STUDENTS ON ONLINE LEARNING
}

\author{
Submitted: \\ 11 Juni 2021 \\ Accepted: \\ 23 November 2021 \\ Published: \\ 31 Januari 2022
}

\author{
Shaden Al Mahabbah Havi*1, Imas Srinana Wardani ${ }^{2}$, Apri \\ Irianto $^{3}$ \\ Shadena176@gmail.com ${ }^{1, i m a s @ u n i p a s b y . a c . i d ~}{ }^{2,}$ \\ apri@unipasby.ac.id ${ }^{3}$ \\ PGSD, FPP, Universitas PGRI Adi Buana Surabaya $1,2,3$ \\ *Corresponding Author
}

\begin{abstract}
This research is motivated by a change in the learning system to be online and has an impact on practicing character education to elementary school students. This is because of the implementation of character education that was previously exemplified directly, but the result of these changes cannot be implemented and creates obstacles and strategies carried out by teachers and parents. The purpose of this study is to identify and identify the strategies and obstacles experienced during the implementation of character education learning in online learning during the Covid 19 pandemic. The research method used was descriptive qualitative research, data collection was carried out through interviews with informants in this study. That is the way teachers and parents, about what processes and obstacles are experienced during online learning. The results of this study are in the form of strategies that have been implemented by schools and parents to deal with obstacles to online character learning, including the implementation of character education learning through habituation at-home activities that reflect discipline and responsibility.
\end{abstract}

Keywords: Character Education, Online Learning, Elementary school students

\section{INTRODUCTION}

Character education is a form of human activity in which there is an educational action aimed at students. The purpose of character education itself is a form of action aimed at shaping a person's self-improvement continuously and training self-skills towards a better life. Efforts to implement character learning at official institutions in shaping and fostering the character of students are needed. A pattern of leadership from the leader of educational institutions and educators will influence the effectiveness of the character education process for students (Ramadhani, 2014). Based on Law No. 20 of 2003 concerning the national learning system in article 3 , which reports that national education plays a role in increasing capabilities and shaping the character and civilization of a dignified nation in the context of the intellectual life of the nation. 
The character itself is values of human attitudes related to God Almighty and oneself, fellow human beings, surrounding environment, and nationality which are manifested in thoughts, behavior, feelings, words, and actions sourced from religious norms, laws, etiquette, culture, and customs. COVID-19 pandemic has had an impact on all aspects of life. The Indonesian government has decided to implement Large-Scale Social Restrictions (PSBB), which will limit activities and reduce socialization with others in the fields of religion, economy, and even education. In school education from elementary, middle, and high school or university through the ministry of education has issued a circular regarding learning from home (Kemendikbud, 2020).

The implementation of online education has also led to a change in the pattern of character learning education. Character education during the COVID-19 pandemic is difficult to implement because it is constrained by many things, however, character education must continue to be carried out considering character education is very important.(Hartati, et al 2019). Character education of students before the COVID-19 pandemic, elementary school students generally imitated the teacher's attitude which was directly imitated by these students. Exemplary is an important aspect to realize character education during the Covid 19 pandemic considering character education as a form of personality that must be implemented in real terms (Rachman, 2020). Doing online learning can affect the character (Suasthi, 2020). The teacher's role which is usually carried out at school must be replaced by someone who accompanies students studying at home. By giving simple real examples amid existing limitations, it is one of the important things to improve student behavior and character changes (Cahyaningrum, et al 2017). If someone's role who accompanies students to study at home cannot play the teacher's duties properly so that the student character created between students who study directly and students who study online will be different (Kemendikbud, 2020).

The application of this education is carried out through the interaction of teachers with students in an atmosphere of learning scope. This education essence is mentoring by educators to deliver knowledge to students. Therefore, education can simply be interpreted as an enlightenment process carried out by teachers to help students obtain education and be able to master the learning materials provided. This paradigm of the learning essence has become a classic with the Covid-19 crisis which has changed the paradigm of learning and education in the world (Fatmadewi, 2020). 
This education system certainly has many obstacles to be experienced by students, parents, teachers let alone schools. These barriers are fundamental in supporting the online education system. Teachers and students in Indonesia do not fully understand the use of technology as a certain obstacle in online learning and besides that, the quota push from the government is also not comprehensive, some of the students do not get a learning quota at all (Putria et al, 2020). These obstacles that have been described show that learning condition which passed online is still not optimal with the expectations and goals set by the government. There are also mistakes above that need to be followed up more deeply so that the online system can run efficiently and effectively to shape the character of students following the educational goals to be achieved. The author collects obstacles and errors that should be predictable so that students can have a responsible character for themselves, especially in their learning.

\section{METHOD}

This research is descriptive qualitative research, which is used to describe everything related to strategies and obstacles in the implementation of character education at SDN Tenggilis Mejoyo 1 Surabaya during the Covid-19 pandemic. This research is classified as field research, namely research that is directly carried out on respondents. This research was carried out during the Covid-19 pandemic in online learning, from November to December 2020.

As for in this study the authors grouped the data sources into two forms:

1. Primary data is the main data analyzed and sourced from observations of student activities and direct interviews with teachers and student guardians related to the impact, character education strategies in the implementation of online learning during the Covid-19 pandemic.

2. Secondary data is complementary data that is still related and connected to the research intend. This secondary data was obtained from data taken from school profiles, conditions of teachers and students, and parents of students at SDN Tenggilis Mejoyo 1 Surabaya.

In this study, the data collection technique used was an observation on 30 students, and interviews were conducted on a sample of 10 parents and a homeroom teacher. The 
instrument used to interview parents is based on family conditions and parents' educational background. The parents' background of the students interviewed was seen from the parents' occupation aspect and the parents' education level. In observation, the instruments used are the constraints of online teaching and learning activities and the online learning process as the inculcation of character education in schools. The data analysis technique used is data reduction, data display, and verification and in this study, the data analysis used is descriptive analysis to describe and introspect data on the implementation of character education during the Covid-19 pandemic learning period at SDN Tenggilis Mejoyo 1 Surabaya.

\section{RESULTS}

The COVID-19 pandemic has changed the teaching and learning system that was originally implemented in schools, now into online learning at home. Online learning is customized to the school's ability. Giving assignments through social media is considered quite effective in online learning practice. However, this creates a new problem in teaching character education, where the teacher who should be a direct example is now having difficulty in implementing it in online learning.

This study is a description of the data exposure that has been obtained from the documentation results and interviews and observations with parents and guardians of students. The data obtained are children's data, teacher personal data and what reasons and obstacles have been obtained, how the learning process from discipline character education and responsibility is carried out by students whether there are obstacles or not. The following table is an aspect that is assessed. 
Table 1. Observation Table

\begin{tabular}{|c|c|c|c|c|c|}
\hline No & Aspect & \multicolumn{4}{|c|}{ Evaluation } \\
\hline \multirow{2}{*}{1} & \multirow{2}{*}{ Discipline } & P1 & $\mathrm{P} 2$ & P3 & $\mathrm{P} 4$ \\
\hline & & $1-4$ & $1-4$ & $1-4$ & $1-4$ \\
\hline & Paying close attention to the teacher & 2 & 3 & 3 & 4 \\
\hline & Uniforms for online learning & 3 & 2 & 3 & 4 \\
\hline & Enter Zoom class on time & 3 & 3 & 3 & 3 \\
\hline & Collect assignments on deadline & 2 & 2 & 4 & 3 \\
\hline \multirow[t]{4}{*}{2} & Responsibility & $1-4$ & $1-4$ & $1-4$ & $1-4$ \\
\hline & Responsible for schoolwork & 2 & 2 & 3 & 4 \\
\hline & The seriousness of the teaching and learning process & 2 & 3 & 4 & 4 \\
\hline & $\begin{array}{l}\text { The responsibility of helping parents, (sweeping, cleaning the } \\
\text { house, etc }\end{array}$ & 2 & 4 & 4 & 4 \\
\hline \multicolumn{2}{|r|}{$\mathrm{P}=\times 100 \frac{\mathrm{m}}{n}$} & $57 \%$ & $67 \%$ & $85 \%$ & $93 \%$ \\
\hline
\end{tabular}

\section{Information}

\section{Source: t-test attachment test 10}

$\mathrm{P}=$ Total percentage

$M=$ Total value

$\mathrm{N}=$ Total score

In this study, several aspects were observed for the running of online learning in the implementation of character education for elementary school students in the habituation of discipline and responsibility. These aspects assessed are aspects of discipline and responsibility, which were carried out for 4 meetings. It is expected that at each meeting every student can show the changes.

In this case, the author chooses a character in the habituation aspect of discipline and responsibility because discipline and responsibility are things that every character must-have for his life. This point is considered very important because every work, word, and deed will always be associated with discipline and responsibility. Because learning is done online, students will usually be more relaxed so that most of them forget the discipline and responsibilities of students like at school, because learning is not done face-to-face. Students will be more relaxed and do as they please because they 
feel that if they study at home there are no written rules that must be obeyed like at school. This is what will be the observations of researchers who will later be observed.

The aspect indicator observed is a marker used by teachers and parents in planning to implement and evaluate schools played by parents because of online education as a result of Covid-19.

Knowing that a school has implemented character education, indicators of discipline and responsibility aspects are set. There are seven aspects observed in this study, these aspects were observed during fieldwork practices involving researchers, these seven aspects were assessed with seven values, namely the first was not good, the second was quite good, the third was good and the fourth was very good.

\section{DISCUSSION}

From the student's activities result that have been described, it is known that seven aspects are observed and assessed during the research process in teaching and learning in character education for elementary school students in online learning. It is known that from day by day there has been an increase, although it is not significant. Because for a child's habit it must be under his feelings and desires. There are times when a child is diligent, his feelings become good, when the child's feelings are not good, he will tend to be angry and lazy.

In that table, it can be seen that at the first meeting with a low percentage of criteria, it can be stated that students are still lazy and some of them have not obeyed the rules because they think they are allowed to act freely if they go to school at home. Looking at the number of observations on the second, third to the fourth day, students showed progress in obeying the rules and regulations in online learning. The parent's responsibility in increasing this requires habituation when the child is SFH (School from home).

Then it can be explained about the strategies and obstacles to implementing character education for elementary school students during the Covid 19 pandemic at SDN Tenggilis Mejoyo 1 as follows: 
a. Strategy for implementing character education for elementary school students in the COVID-19 pandemic

1.) Cooperate well with teachers and parents so that students' character education can run and make a really good character. This strategy for implementing character education requires support and guidance from the closest people which the teacher's role when the child is at home is their parent consisting of father and mother. Without harmony between character education at school and outside school, the child's character will not run optimally (Maunah, 2016). This also makes children have a sense of responsibility from the habits taught by parents at home. This is in line with what was stated by (Lickona, 2013) that to invite parents in moral education, everything must begin with discipline. Collaboration between parents and teachers can be learning that shapes the development of students to develop knowledge (cognitive) and parental involvement (Setiawan, 2021). This collaboration can be done by sending a copy of the plan or collaboration between parents and teachers to make the teacher know what behavior is being carried out.

2.) Giving awards to students is a form of motivation for the character of learning discipline and student responsibility so that it becomes a habit that is always done by students. This is in line with what was stated (Kosim, 2012)that giving rewards or prizes can be used as an educational tool for children to achieve targets and do good attitudes or things. These rewards can also be a motivation to do positive things.

3.) Online learning was changed from the original one-hour subject, which was minimized to a maximum of 30 minutes so that students did not boredom and the rest of the time was used for discussion. Changes in online learning time to avoid boredom and ineffectiveness in learning. Online learning conducted for elementary school children is considered less effective if it is presented only about 70\%.(Purwanto, 2020)

4.) Providing infrastructure for online learning is also in line with the opinion (Purwanto, 2020)which stated that maximizing the use of infrastructure such as learning media is very influential in the online teaching and learning process. To maximize the parents' role to strengthen character education for 
students, a strategy is needed that can maximize the parents' role in efforts to strengthen character education for students (Christian, 2018). The family becomes a party that has an important role in character development, when children are noticed for their existence and their needs are fulfilled by parents, their character education will grow well. (Simarmata, 2017)

5.) Because true character education will be shaped in children if the guidance and habits of their parents are also created. This habituation is also carried out so that children do not forget and continue to carry out habits as taught at school so that children also continue to carry out their obligations as students as they are done at school. (Sabidah, 2015) stated that realizing a culture of character in schools that is horizontal can be done through a habituation approach, example, and a persuasive approach or subtly asking school members, by giving reasons and good prospects that can convince them. Exemplary is also an important aspect in realizing character education because character education is a form of personality that must be done in real life and not only speaking but must be proven in the form of exemplary carried out by all parties.(Santoso, 2020).

\section{b. Obstacles in learning character education in the online system during the COVID-19 pandemic for elementary school students}

1.) Not familiar with the online system, according to the opinion of parents and guardians of students interviewed, on average, they think that online learning is not working optimally. It can be seen from the practice that this online learning seems straightforward and impromptu because of the conditions that cause this. There are still many teachers and parents who do not understand the application media used for online schools. This is in line with what was stated (Fatmadewi, 2020) that the existence of distance learning methods makes students need time to adapt and they face new changes that will indirectly affect their learning absorption. Another impact felt by teachers is that not all are proficient in using internet technology or social media as a learning tool. 
2.) The parents role who are less assertive in the implementation of children's character education in the implementation of discipline and responsibility character education is very needed for students. This lack of firmness in the role of parents can create obstacles in the implementation of student character which causes children to rely on others to do their work so that their sense of discipline and responsibility is not embedded properly. This is in line with the opinion(Lickona, 2013)that the parent's role is very important in forming a good moral character. So the firmness and discipline of parents will affect the forming of a child's character.

3.) The habit of supporting discipline and responsibility character education is not effective and efficient because it is done at home while children are usually just playing at home and forgetting about responsibility and discipline like what is taught in school when face-to-face at school. Whereas character education in learning during this pandemic should be able to develop good student character and can be implemented in social life (Intania, 2020). But in fact, according to (Syarbini, 2014) character education in the family environment is not optimal or has not been properly conceptualized. It is also proven in this study that parents are less effective in implementing this habit of discipline and responsibility because the rules at home are not written and regulated as they are in school, so children will tend to disobey them. This was also conveyed by parents that children tend to be more spoiled and argue with parents who are very different from teachers. There is also a positive relationship between the positive behavior of parents and children's attitudes.(Marhoja, 2014). Parents also should not be tired and must remain enthusiastic in making every effort to improve behavior and personality based on character values(Supreme, 2018).

4.) Infrastructure facilities for the implementation of online education that is not yet complete implement character education not going well, parents who complain about the facilities and infrastructure that should be prepared for their children in online learning, because they have to alternate with the interests of their parents or sometimes take turns with their brother or sister so that they cannot collect assignments or take online lessons optimally and on 
time, this also hinders the implementation of discipline character education in children. Parents also complained about the internet quota that not all parents and guardians of students received the quota assistance. In addition to this, based on the results of interviews with parents or teachers, quotas are one of the main factors inhibiting this online learning because there is still an uneven internet quota from the government. The lack of smoothness of online learning also makes the implementation of character education hampered in this online learning period. In line with what was said by(Fatmadewi, 2020) that one of the obstacles for parents is the additional cost of buying an internet quota which causes an increase in the burden of parental expenses.

5.) Cultivation of character education habituation of discipline and responsibility that is less than maximum. The inculcation of discipline and responsibility carried out by parents is recognized if the child will be more spoiled at home to his parents and the guardian's parents will also spoil him. Although parents apply a system of sanctions to their children if they do not behave in a disciplined and responsible manner, some parents leave children. According to (Muslihkin, 2020) mentioned that parents lack awareness in character education for their children, parents' busyness, parental ignorance, and how to form good children's character. This is in line with research conducted by (Krisnawati, 2016) in this study, it is explained that the supporting and inhibiting factors of teachers in fostering cooperation with parents form the character of students' discipline and responsibility.

The teacher's efforts in shaping a student's character include socializing with parents, making agreements to combat the impact of using media, establishing good communication between parents and teachers.

\section{CONCLUSION}

Based on research on the implementation of character education for elementary school students during online learning as a result of Covid-19, it is concluded that the practice of character education carried out by online learning certainly has many obstacles because learning if not face to face with the teacher will cause a lot of 
misunderstandings between teachers with students, teachers with parents of students who cause these obstacles, when meeting face-to-face with teachers and their friends who are usually competitors so that they have their learning spirit, less effective of online learning for character education for students at SDN Tenggilis Mejoyo I Surabaya, which where there are still many practices that have not been implemented in character education.

Implementation of character education discipline and responsibility of the students of SDN Tenggilis Mejoyo I in online learning, there is a strategy carried out in learning character education through online, namely teaching if the school will fully teach the implementation of education then every value that will be instilled must always be conveyed by teachers through direct learning (as a subject) in which the values of character education must be strengthened by the values of environmental management and activities in the school environment which are replaced with activities in the home environment.

\section{REFERENCES}

Agung, L. (2018). Character Education Integration in Social Studies Learning. Historia: Jurnal Pendidik dan Peneliti Sejarah, 12(2), 392.

Cahyaningrum, E. S., Sudaryanti, S., \& Purwanto, N. A. (2017). Pengembangan NilaiNilai Karakter Anak Usia Dini Melalui Pembiasaan Dan Keteladanan. Jurnal Pendidikan Anak, 6(2), 203-213.

Fatmadewi, W. A. (2020). Dampak Covid 19 terhadap implementasi pembelajaran daring di sekolah. Ilmu Pendidikan, 2(No 1).

Hartati, N. S., Thahir, A., \& Fauzan, A. (2019). Manajemen Program Penguatan Pendidikan Karakter Melalui Pembelajaran Daring dan Luring di Masa Pandemi Covid 19-New Norma. Journal of Chemical Information and Modeling, 53(9), 1689-1699.

Intania, E. V. (2020). The role of character education in learning during the COVID-19 pandemic Peran pendidikan karakter dalam pembelajaran selama pandemi. Jurnal Penelitian Ilmu Pendidikan, 13(2), 129-136. 
Kosim. (2012). Urgensi Pendidikan Karakter. Social and Islamic Cultue.

Krisnawati, A. (2016). Kerjasama Guru Dengan Orang Tua Membentuk Karakter Disiplin Siswa Kelas V SD Negri Gembongan. Jurnal Pendidikan Guru Sekolah Dasar, 18. Yogyakarta.

Kristiawan, M., \& Bengkulu, U. (2018). Strategi Sekolah Dalam Penguatan Pendidikan Karakter Bagi, (December 2017).

Lickona, T. (2013). Mendidik untuk membentuk karakter. Jakarta: Bumi Aksara.

Marhoja. (2014). Hubungan Keteladanan Orang Tua Terhadap, 2(1), 14-23.

Maunah, B. (2016). Implementasi Pendidikan Karakter Dalam Pembentukan

Kepribadian Holistik Siswa. Jurnal Pendidikan Karakter, (1), 90-101.

Muslihkin. (2020). Nilai-Nilai Pendidikan Karakter Dalam Pembelajaran Pendidikan Agama Islam. Jurnal Penelitian Pendidikan Islam, 2(1).

Purwanto. (2020). Studi Ekspolratif Dampak Pandemi Covid 19 Terhadap Proses

Pembelajaran onlien di Sekolah Dasar. Journal of Education and Psychology and Counseling, 2(1), 1-12.

Ramadhani, M. A. (2014). Lingkungan Pendidikan dalam Implementasi Pendidikan Karakter. Jurnal Pendidikan Universitas Garut, 08(01), 28-37.

Sabidah, R. A. (2015). Strategi dan Implementasi Pelaksanaan Pendidikan Karakter di SMP 9 Yogyakarta. Pendiidkan.

Santoso, Suyahmo, Maman, R., \& Utomo, C. B. (2020). Urgensi Pendidikan Karakter Pada Masa Pandemi Covid 19. Seminar Nasional Pascasarjana Universitas Negeri Semarang, 558-563.

Setiawan, A. (2021). Pendidikan Karakter pada Peserta Didik di Masa Pandemi Covid19 Berbasis Keluarga, 7(1), 319-327.

Simarmata, H. D. (2017). Pendidikan Karakter Berbasis Keluarga. Ta'dib:Journal of Islamic Education (Jurnal Pendidikan Islam), 9(01), 41-59.

Suasthi, I. G. A., \& Suadnyana, ida bagus putu eka. (2020). Membangun Karakter “ Genius " Anak Tetap Belajar Dari Rumah Selama Pandemi Covid - 19 Pada 
Sekolah Suta Dharma Ubud Gianyar. Cetta: Jurnal Ilmu Pendidikan, 3(3), 431451. Retrieved from

http://jayapanguspress.penerbit.org/index.php/cetta\%0AJayapangus

Syarbini. (2014). Model Pendidikan Karakter dalam kelurga. Jakarta: PT Elex Media Kumpotindo. 